BMJ omtaler nevnte type iatrogene overdødelighet som «I beste fall en unnlatelse av å handle på bevis; i verste fall en form for dødelig diskriminering.» ("At best a failure to act on evidence; at worst a form of lethal discrimination.») (10).

\section{Svein Reseland}

sreselan@online.no

Svein Reseland (f. 1952) er ingeniør.

Ingen oppgitte interessekonflikter.

\section{Litteratur}

1. Lien L, Huus G, Morken G. Psykisk syke lever kortere. Tidsskr Nor Legeforen 2015; 135: 246-8.

2. Nyt om bivirkninger juni 2015. https://sundhedsstyrelsen.dk (6.5.2015)

3. Greater Mortality Risk With Antipsychotics in Parkinson's. www.medicalnewstoday.com (19.6.2015).

4. Andrews PW, Thomson JA Jr, Amstadter A et al. Primum non nocere: an evolutionary analysis of whether antidepressants do more harm than good. Front Psychol 2012; 3: 117

5. Gøtzsche PC, Young AH, Crace J. Does long term use of psychiatric drugs cause more harm than good? BMJ 2015; 350: h2435.

6. Muench J, Hamer AM. Adverse effects of antipsychotic medications. Am Fam Physician 2010: 81: 617-22.

7. Reseland S. RE: Studier som stikkes under stol. http://tidsskriftet.no/article/ 3316706 (2.9.2015)

8. Halmøy A. Tankevekkende om pårørendes følelse av maktesløshet. Tidsskr Nor Legeforen 2014: 134: 957

. Sigvart A. Som avtalt med legen. Oslo: Nova Forlag, 2013.

10. Thornicroft G. Premature death among people with mental illness. BMJ 2013; 346: $\{2969$.

\section{Lien og medarbeidere svarer:}

Takk for kommentar fra Svein Reseland til vår artikkel (1). Kommentaren tar opp i hvilken grad bruk av psykofarmaka, og da spesielt antipsykotika, bidrar til forkortet levetid blant mennesker med psykiske lidelser. De fleste mennesker i de store gruppene med psykiske lidelser vi omtalte i vår kronikk, har ikke vært behandlet med antipsykotika, eventuelt har det vært brukt antipsykotika i korte perioder. Om antipsykotika bidrar til forkortet (2) eller forlenget liv (3) hos mennesker som bruker preparatene, er gjenstand for en bred debatt både i medisinske tidsskrift (2) og dagspressen, sist i Klassekampen våren 2015.

Vår vurdering er at dokumentasjonen for forlenget liv er tyngre enn det motsatte (3), men vi ser behovet for videre studier og kunnskapsoppsummeringer. Både helseforetakene og Helsedirektoratet vil ta initiativ for å bedre oppfølging og behandling av somatisk sykdom hos denne pasientgruppen.

Sist i kommentaren refererer Reseland BMJ (4) til å omtale «iatrogen overdødelighet» som «I beste fall en unnlatelse av å handle på bevis; i verste fall en form for dødelig diskriminering.». Slik vi leser denne lederartikkelen i BMJ, tar den opp mye av bredden av sosioøkonomiske, sykdomsrelaterte og behandlingsrelaterte årsaker til forkortet liv for mennesker med psykiske lidelser.

\section{Lars Lien}

lars.lien@medisin.uio.no

Gitte Huus

Gunnar Morken

Lars Lien (f. 1960) er leder/professor ved Sykehuset Innlandet/Høgskolen i Hedmark.

Ingen oppgitte interessekonflikter.

Gitte Huus (f. 1967) er cand.polit., sosialantropolog og avdelingsdirektør for Avdeling psykisk helsevern og rus i Helsedirektoratet.

Ingen oppgitte interessekonflikter.

Gunnar Morken (f. 1956) er professor i psykiatri ved Norges teknisknaturvitenskapelige universitet, overlege i Divisjon psykisk helsevern, St. Olavs hospital, og avdelingssjef for Avdeling for forskning og utvikling samme sted.

Ingen oppgitte interessekonflikter
Litteratur

1. Lien L, Huus G, Morken G. Psykisk syke lever kortere. Tidsskr Nor Legeforen 2015: 135: 246-8.

2. Gøtzsche $\mathrm{PC}$, Young $\mathrm{AH}$, Crace J. Does long term use of psychiatric drugs cause more harm than good? BMJ 2015; 350: h2435

3. Tiihonen J, Lönnqvist J, Wahlbeck K et al. 11-year follow-up of mortality in patients with schizophrenia: a population-based cohort study (FIN11 study). Lancet 2009: 374: 620-7.

4. Thornicroft G. Premature death among people with mental illness. BMJ 2013; 346: 12969

\section{Re: Ulike retningslinjer for behandling av prostatakreft}

I min kommentarartikkel i Tidsskriftet nr. 10/2015 redegjorde jeg for at norske retningslinjer avviker fra de europeiske retningslinjene på flere viktige punkter (1). På vegne av forfatterpanelet for de norske retningslinjene viser onkolog Solberg og medarbeidere i Brev til redaktøren-spalten i nr. 12-13/2015 til et syv år gammelt leserbrev i Tidsskriftet, men begrunner ellers ikke avvikene som gjelder hormonbehandling. Uten evidens for økt overlevelse eller redusert sykelighet, blir monoterapi med antiandrogener stående som en metode som kun påvirker tumormarkøren og ikke tumoren. Når behandlingen dessuten er beheftet med alvorlige bivirkninger, blir det naturlig å vurdere om den er etisk forsvarlig. Brevet som Solberg viser til, har ingen relevans for retningslinjer anno 2015.

Solberg forklarer ikke hvorfor det i de norske retningslinjene opplyses at primær strålebehandling med 66-70Gy har vært vanlig i Norge i lang tid. Siden residivfrekvensen er rapportert å være opptil $67 \%$ i andre land, bør pasientene få vite om behandlingen er godkjent av REK og hvor mange som er endt opp med livslang kastrasjonsbehandling (2). Når Gustavsen i sitt innlegg skriver at alle hans pasienter har fått 70Gy, blir det vanskelig å tro på Solbergs forsikringer om at dose-eskalert EBRT er vanlig i Norge.

I studiene som Solberg viser til for å begrunne 70Gy som standard stråledose, har man sett på effekten av 70Gy som tillegg til permanent kastrasjon hos pasienter med lokalavansert sykdom $(3,4)$. Funn i denne pasientgruppen kan ikke tas til inntekt for at 70Gy bør være standarddose for pasienter med lokalisert sykdom og som behandles uten permanent kastrasjon. Kubans artikkel, som viser signifikante forskjeller i favør av 78Gy, er kun én av flere referanser som EAU støtter seg til når de anbefaler en høyere standard stråledose enn det Solberg gjør i de norske retningslinjene (5).

I studien som Solberg legger til grunn for å anbefale tilleggsbestråling med HDR-braky, er det kun benyttet 55Gy som ekstern stråledose i kontrollarmen (6). På grunn av uvanlig høy forekomst av tilbakefall, mener EAU at det er behov for flere doseeskalerte EBRT-studier der HDR-braky er eneste variabel, før man kan anbefale tilleggsbestråling med HDR-braky. Min uttalelse om at forskningen på brakyterapi i Norge var stanset, var basert på skriftlig korrespondanse med Lilleby 15.05.2014 angående en pasient, og opplysningen ble bekreftet skriftlig av lederen for prostatasenteret 26.08. 2014.

Solberg viser til at det ikke foreligger randomiserte studier som sammenligner effekten av ulike lokale salvagebehandlinger etter mislykket stråleterapi. En viktig grunn til dette er at foreliggende evidens gir pasientene tilstrekkelig grunnlag til selv å velge metode. De aller fleste velger bort kastrasjon, som er den mest benyttede salvagebehandlingen ved tilbakefall etter strålebehandling, og dermed den naturlige kontrollbehandling i sammenlignende studier (10). Solbergs presisering av at HIFU er eksperimentell behandling er berettiget, men skaper store problemer både for forfatterpanelet, prosjekteier og for utenlandskontoret, fordi salvagebehandlingen med HIFU som har pågått i ni år, gis uten godkjent protokoll $(8,9)$.

Med unntak av stråle- og cellegiftbehandling, står urologene for det aller meste av klinisk diagnostikk, behandling og kontroll av menn med prostatakreft. Norske kliniske retningslinjer er imidlertid 
skrevet av seks onkologer og fire urologer. De europeiske retningslinjene er skrevet av ti urologer, to onkologer og en som har begge spesialitetene. Alle er internasjonale, faglige autoriteter.

I 1988 ble ledende amerikanske fagpersoner enige om at radikal prostatektomi og radikal strålebehandling var likeverdige behandlinger (10). Det ble etter hvert klart at det kun var et ønske om fordragelighet som bar påstanden. Dette var ikke pasientene tjent med, og i 2015 fjernet EAU referansen fra sine retningslinjer i erkjennelse av at det er gjennom meningsbrytning og kritisk vurdering av evidens at fagene utvikles.

\section{Truls E. Bjerklund Johansen}

t.e.b.johansen@medisin.uio.no

Truls E. Bjerklund Johansen (f.1951) er spesialist i generell kirurgi og i urologi, professor ved Universitetet i Oslo, overlege ved Urologisk avdeling, Oslo universitetssykehus, og har flere ulønnede verv i European Association of Urology

Ingen oppgitte interessekonflikter.

\section{Litteratur}

1. Johansen TEB. Ulike retningslinjer for behandling av prostatakreft. Tidsskr Nor Legeforen 2015; 135: 924-5.

2. Pisansky TM, Kahn MJ, Rasp GM et al. A multiple prognostic index predictive of disease outcome after irradiation for clinically localized prostate carcinoma. Cancer 1997; 79: 337-44.

3. Warde P, Mason M, Ding K et al. Combined androgen deprivation therapy and radiation therapy for locally advanced prostate cancer: a randomised, phase 3 trial. Lancet 2011; 378: 2104-11.

4. Widmark A, Klepp 0 , Solberg A et al. Endocrine treatment with or without radiotherapy, in locally advanced prostate cancer (SPCG-7/SFU0-3): an open randomised phase III trial. Lancet 2009; 373: $301-8$. . Erratum in: Lancet. 2009 Apr 4; 373(9670): 1174

5. Kuban DA, Levy LB, Cheung MR et al. Long-term failure patterns and survival in a randomized dose-escalation trial for prostate cancer. Who dies of disease? Int J Radiat Oncol Biol Phys 2011; 79: 1310-7

6. Hoskin PJ, Rojas AM, Bownes PJ et al. Randomised trial of external beam radiotherapy alone or combined with high-dose-rate brachytherapy boost for localised prostate cancer. Radiother Oncol 2012; 103: 217-22.

7. Salji M, Jones R, Paul J et al. Feasibility study of a randomised controlled trial to compare (deferred) androgen deprivation therapy and cryotherapy in men with localised radiation-recurrent prostate cancer. Br J Cancer 2014; 111: 424-9.

8. https://helseforskning.etikkom.no/ikbViewer/page/prosjekterirek/ prosjektregister/prosjekt?p document id $=188541 \&$ p parent id $=196196 \&$ ikb LanguageCode=us (15.7.2015)

9. Helseforskningsloven § 54. https://lovdata.no/dokument/NL/lov/ 2008-06-20-44\#KAPITTEL_10 (2.9.2015).

10. Consensus statement: The management of clinically localized prostate cancer. National Institutes of Health Consensus Development Panel (no authors listed). $\mathrm{NCl}$ Monogr 1988: 7: 3-6. www.ncbi.nlm.nih.gov/pubmed/3050539 (15.7.2015).

\section{Re: Den vanskelige prostatakreften}

Det er et krav at leger som uttaler seg om prostatakreft opplyser om interesser som kan påvirke deres faglige vurderinger $(1,2)$. I Tidsskriftet nr. 11/2015 kommenterer Lilleby og medarbeidere min lederartikkel om prostatakreft $(3,1)$. Lilleby og hans medforfattere med adresse ved et privat institutt, har gjort det klart at intensjonen med artikkelen om LDR-braky var å bidra til at metoden blir introdusert i Norge, men ingen av dem oppgir interessekonflikter (3).

Lilleby og Raabe skriver at flere uro-onkologer i Norge (dem selv?) behersker bildestyrt nålebasert behandling av kreft i prostata (2). Uttalelsen undrer meg, fordi den tekniske utførelsen av slik behandling ikke blir omtalt verken i målbeskrivelsen eller kurstilbudet for norske onkologer, og radiologer og urologer bruker flere år på å lære seg teknikken som ledd i sin spesialistutdanning. Jeg mener denne uttalelsen viser at det er behov for å formalisere kvalifikasjonskravene til endokavitær ultralyddiagnostikk og bildestyrte prosedyrer.

Det er vanskelig for pasienter å leve med en kreftsvulst som ikke krever behandling, og det er vanskelig for leger å holde fast ved at dette er en situasjon man ikke bør forsøke å behandle seg ut av. Vanskelighetene tilsier at dette er en situasjon man skal unngå å screene seg inn i, og nettopp derfor fraråder helsemyndigheter i alle vestlige land PSA-basert screening. For å gjøre det lettere å akseptere at lavrisikosvulster ikke skal behandles, er det nylig fremmet forslag om å endre betegnelsen på kreft med Gleason skår 6 til kreft med prognosegruppe 1 på en skala fra $1-5$ (4).

Truls E. Bjerklund Johansen
t.e.b.johansen@medisin.uio.no

Truls E. Bjerklund Johansen (f.1951) er spesialist i generell kirurgi og i urologi, professor ved Universitetet i Oslo, overlege ved Urologisk avdeling, Oslo universitetssykehus, og har flere ulønnede verv i European Association of Urology.

Ingen oppgitte interessekonflikter.

Litteratur

1. Johansen TEB. Den vanskelige prostatakreften. Tidsskr Nor Legeforen 2015 135: 508.

2. Lilleby W, Raabe NK, Normann M. Lavdoserate brakyterapi av pasienter med lavrisiko prostatakreft. Tidsskr Nor Legeforen 2015; 135: 548-52.

3. Lilleby W, Raabe NK, Normann M. Re: Den vanskelige prostatakreften. Tidsskr Nor Legeforen 2015; 135: 1009

4. Loeb S, Montorsi F, Catto JW. Future-proofing Gleason Grading: What to Call Gleason 6 Prostate Cancer? Eur Urol 2015; 68: 1-2.

\section{Re: - Stortrives som medisinstudenter i Budapest}

I Tidsskriftet nr. 14/2015 leste jeg et intervju med norske medisinstudenter i Budapest (1). Studentene stortrives. De studerer, men har også gjort en interessant observasjon om at vi har det meget godt i Norge, fordi på norske sykehus er det toalettpapir for pasienter og personale, mens i Budapest må folk ta toalettpapir med seg hjemmefra. Det er morsomt. Jeg har hørt flere forslag på hva velstand betyr, men at velstand også betyr at det finnes toalettpapir på sykehus synes jeg er originalt. Studentene i Budapest har antakelig lite kjennskap til daglige og mer alvorlige problemer enn toalettpapir på de norske sykehus. Ett av problemene er korridorpasienter. I andre land i Europa har veldig få sykehus, spesielt universitetssykehus, pasienter liggende på gangen. Dette er en skam. Helsetjenesten, til tross for at man i Norge betaler ekstremt høy skatt, fungerer dårlig på grunn av at det ofte er lang ventetid til utredning og behandling. I Norge har ca. 500000 privat helseforsikring som garanterer rask legehjelp.

Jeg synes at vi har det rimelig bra i Norge, men vi kunne hatt det mye bedre, blant annet i helsevesenet, dersom man brukte pengene som ligger i oljefondet med «hodet». Pengene kan plutselig bli betydelig mindre eller forsvinne helt, og Norge er igjen like fattig som det var tidligere. Sannsynligvis blir det ikke råd til medisiner eller utstyr, og heller ikke til toalettpapir på sykehus.

\section{Grzegorz Gradek}

gradek@online.no

Grzegorz Gradek (f. 1953) er spesialist i hjerte- og lungemedisin ved Hjerte-og Lungesenteret, Bergen.

Ingen oppgitte interessekonflikter.

\section{Litteratur}

1. Kongsvik LT. - Stortrives som medisinstudenter i Budapest. Tidsskr Nor Legeforen 2015; 135: 1326. 